\title{
Documentário
}

\section{O DIÁlogo DE MELOS: o discurso do poder}

\author{
Anna Lia Amaral de Almeida Prado ${ }^{1}$
}

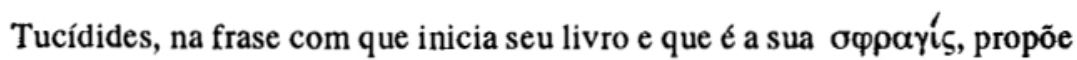
como seu tema "a guerra dos peloponésios e atenienses, como a fizeram uns contra os outros" (I, 1). Essa formulação poderia fazer-nos esperar um registro pormenorizado, fiel e linear das ações bélicas, uma crônica militar. Muito maior, porém, é a ambição e o feito de Tucídides que, segundo expressão sua, quis deixar

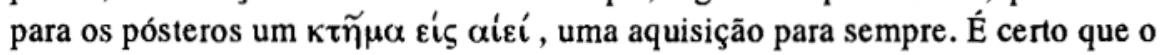
historiador busca um relato preciso, mas a $\alpha \kappa \rho i ́ \beta \varepsilon \iota \alpha$ é para ele uma exigência

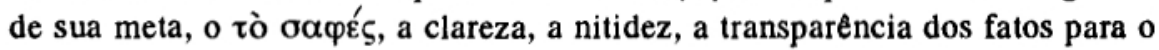
olhar e para a inteligência do leitor.

Tucídides critica $(I, 22)$ aqueles que recebem $\alpha \beta \alpha \sigma \alpha v i \sigma \tau \omega \varsigma$ os dados da tradição, isto é, sem submetê-los à prova. O advérbio $\alpha \beta \alpha \sigma \alpha v i ́ \sigma \tau \omega \varsigma$, através do verbo $\beta \alpha \sigma \alpha v i \zeta ̧ \varepsilon \imath v$, é derivado de $\beta a ́ \sigma \alpha v o \varsigma$. $\beta \alpha \sigma \alpha \alpha v o s$ é o nome do basalto, a pedra de toque, através da qual se reconhece a autenticidade do ouro. É também o termo empregado para designar a tortura a que podiam ser submetidos os escravos num tribunal. Ele, ao contrário desses a quem critica, está acostumado

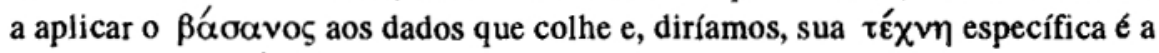
do $\beta \alpha \sigma \alpha v i \sigma \tau$ '́, aquele que põe em questão, aquele que tortura, não escravos-testemunhas, mas os dados para que, fazendo cair o disfarce, indo além do aparente, do simplesmente alegado, mostre o que de fato eles significam. Usando uma expressão de Platão na República (361 c) onde se fala de alguém,

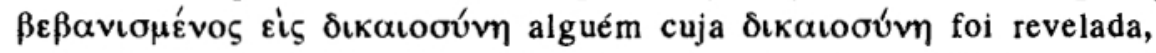
evidenciada, poderíamos falar que Tucídides ambiciona uma exposição histórica

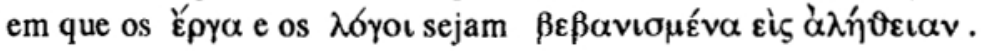

1 Depto. de Letras Clássicas e Vernáculas-FFLCH/USP. 
PRADO, Anna Lia Amaral de Almeida. O diálogo de Melos: o discurso do poder.

Tucídides nos desvenda muito da verdade sobre a guerra dos peloponésios e atenienses, quando mostra que ela foi fundamentalmente uma luta pela manutenção do império de Atenas e que a história dessa guerra se confunde com a história do imperialismo ateniense. Fica claro pela exposição de Tucídides que, apesar da multiplicidade de frentes de batalha, de diferentes adversários eventuais, de vitórias e derrotas de lado a lado, apesar de tréguas e armistícios ou alianças, houve uma guerra só durante vinte e sete anos. Esparta e Atenas lutaram de 431 a 404 a.C, e a guerra só terminou quando os lacedônios puseram fim ao império ateniense e ocuparam os Grandes Muros e o Pireu (Tuc. V, 26). Expondo essa longa cadeia de acontecimentos que acompanham o crescimento

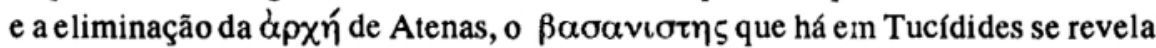
e ele, ao mesmo tempo que registra com precisão e fidelidade os lances da guerra dos peloponésios e atenienses, como eles a fizeram uns contra os outros, faz com que os fatos que registra falem sobre a natureza do poder, sobre suas relações com o direito e a justiça. Essa questão está no cerne da obra tucidideana e está presente em toda sua extensão, desde a chamada Arqueologia com que a obra inicia. Há, porém, passagens em que a problemática relativa ao poder é tratada de modo mais direto. Entre essas passagens, aparece como questão privilegiada para reflexão sobre esse tema o Diálogo de Melos (Tuc. V, 84-116).

A guerra tinha começado em 431 A.C. com a invasão de Platéias pelos tebanos e, só depois de dez anos, em 421, quando morrem em Anfílopis o ateniense Cleão e o espartiata Brásidas, propugnadores da luta sem tréguas, Atenas e Esparta, já exaustas com a perda de muitos homens, já sem recursos financeiros e bélicos suficientes, fazem a paz. Firmaram um tratado, a Paz de Nícias e, além disso, fizeram uma aliança. Mesmo assim a paz não voltou a reinar no mundo grego e apenas passou a haver uma abstenção de armas, uma

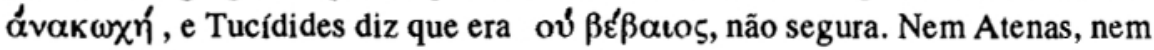
Esparta praticava atos de agressão contra o território adversário, mas uma procurava prejudicar a outra no exterior, em sua zona de influência.

Os acontecimentos desse período de paz insegura -, Tucídides os inclui em sua obra como um momento da guerra dos peloponésios e atenienses e eles ocupam a maior parte de livro V da História da Guerra do Peloponeso. Os comentadores de Tucídides concordam em considerar essa secção de sua obra como inacabada. Aĺ a apresentação dos fatos, apesar de pormenorizada, é muitas vezes pouco clara. É certo que para isso contribui a multiplicidade das frentes de luta, tanto militares quanto políticas, e também os artifícios de um complicado 
jogo diplomático. Entretanto, a marca mais evidente da falta de acabamento do livro $\mathrm{V}$ é a ausência de discursos, que são um elemento essencial na exposição histórica tucidideana. Os discursos são momentos em que o historiador, tomando distancia dos fatos, através dos $\lambda$ oyo dos protagonistas da história, procura tornar explícito o $\lambda$ oyos que sustenta os $\varepsilon \rho \gamma \alpha$. Faltando-lhe os discursos, o livro $\mathrm{V}$ parece muitas vezes os registros de material ainda em estado bruto, ainda não elaborado pelo historiador. Só nos capítulos finais desse livro, ao tratar de uma expedição militar de Atenas contra Melos, Tucídides, além de relatar os acontecimentos: invasão, ultimatum, resistência e rendição, revela através de um

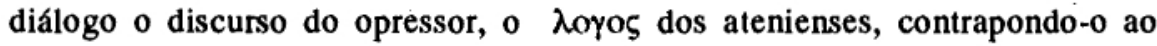
discurso do oprimido, o $\lambda$ oyos dos mélios.

Diz-nos Tucídides $(\mathrm{V}, 84)$ que a expedição contra a ilha de Melos foi enviada no início do verão de 416 A.C. A cidade dos mélios era de origem dória, tinha governo oligárquico mas, até então, tinha-se mantido neutra no conflito que envolvia atenienses e peloponésios. Os invasores vieram com grande aparato, o que Tucídides registra: 38 navios, 2.700 hoplitas e 320 arqueiros e, antes de iniciar as hostilidades, apresentaram-se alguns delegados para discutir a situação da cidade. Os mélios não os levaram diante da assembléia, mas com eles se reuniram no Conselho. Nesse momento da narrativa, que é rápida e seca, encaixa-se o diálogo que vamos analisar.

Já se disse (Howald, Vom Geist der antiker Geschichtschreibung, München/Berlin 1944) ${ }^{2}$ que nem sempre Tucídides escolhe os fatos mais importantes para integrar sua exposição e que, muitas vezes, ocorre justamente o contrário: o que ele escolhe passa a ter importância. A operação militar realizada contra Melos durou apenas um verão e nada representou para o império ateniense em termos de ganho de poder ou de território, nem teve peso para a decisão da guerra. Apesar disso a passagem dedicada a esse episódio e que inclui o Diálogo é uma das mais importantes da História da Guerra do Peloponeso, não porque seja o registro de um comovente exemplo histórico, e datado, da velha fábula do gavião e do rouxinol ou de falcões que agridem pombas, ou porque fale de uma situação muito semelhante a muitas que ainda hoje vivemos. É importante porque nos faz ouvir o discurso ateniense sobre o imperialismo ateniense, é importante como um momento de auto-revelação de Atenas. Na fala dos 
PRADO, Anna Lia Amaral de Almeida. O diálogo de Melos: o discurso do poder.

atenienses se desnuda fria e cruamente a ideologia do poder pela qual a opressão e o domínio exercido sobre o mais fraco se justifica como um direito natural, que o mais forte tem e que exclui todo e qualquer apelo à idéia de justiça, às normas de convivência social, ao respeito às prescrições morais e religiosas.

A realização de conversações a portas fechadas, sem a presença do povo reunido em assembléia, não seria impossível numa cidade como Melos em que o governo estava nas mãos de poucos, que era uma oligarquia. Também verossímil que, numa reuniāo de que participavam apenas delegados atenienses e membros do conselho dos mélios - não sabemos quem e quantos eram os mélios e os atenienses - , as falas não tivessem seguido os padrōes da estruturação formal das demegorias. Entretanto, é certo que não foram razões de verossimilhança que levaram Tucídides a preferir, para este caso, um diálogo a uma antilogia como era seu costume.

Já Dionísio de Halicarnasso (De Thucydide 37) comenta o caráter dramático que o diálogo assume quando Tucídides, o narrador, deixa de intervir e passa apenas a indicar, antes do registro direto das falas, o nome do locutor.

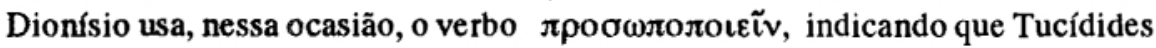
passa a tratar os atenienses e os mélios como personagens de um drama, como protagonistas de uma peça de teatro. Parece-me entretanto, que o caráter dramático dessa passagem não deriva apenas da forma de apresentação, porque só isso não bastaria para explicar o $\pi \alpha \vartheta \emptyset$ os, que atinge o leitor do Diálogo. Há, de fato, uma ação que vemos desenrolar num primeiro plano, na cena que é o

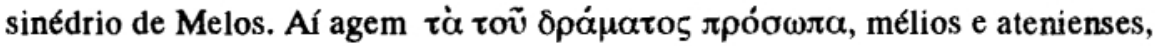
através das palavras que pronunciam. Aí está em curso um ó $\gamma \dot{\omega} v$ hó $\gamma \omega v$ que se mostrará tão eficiente e efetivo quanto tantas manobras bélicas narradas por Tucídides. Há, porém, um segundo plano, o lado de fora da sala do conselho, onde estão os hoplitas, os arqueiros e, mais longe, as trirremes atenienses. $\mathrm{O}$ segundo plano é a frente de combate e aí a luta está suspensa, na expectativa do desenlace do $\alpha \dot{\alpha} \dot{\omega} v$ hó $\gamma \omega v$. A luta nesse $\alpha \hat{\gamma} \dot{\omega} v$, entretanto, não nos parece uma luta em campo aberto, com oportunidades iguais para ambos adversários no ataque e na retirada, mas um assédio em que o mais forte, tendo imobilizado o mais fraco, pouco a pouco vai-lhe roubando as armas e, ao mesmo tempo, as oportunidades de escapada. Assim, poderíamos falar de uma sobreposição de planos: o que acontece no sinédrio é uma luta que reproduz, na situação de um discurso, as operaçöes reais de um assédio. Isso equivale a dizer que vemos o diálogo como uma metáfora da invasão, assédio e extermínio da cidade de Melos. 
Tanto a narrativa quanto o diálogo dão conta de um assédio, um feito pela força dos navios, pelas lanças dos hoplitas e pelas flechas dos arqueiros, a partir da circunvalação, o outro, exercido como uma única arma, a palavra. Tanto a narrativa quanto o diálogo, mas mais ainda o diálogo, como metáfora da agressão

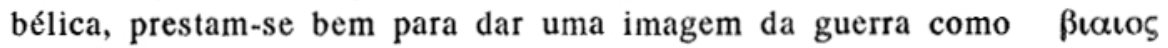

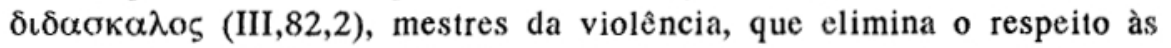
convenções da justiça, aos tratados de paz, às tradições morais e religiosas $\mathrm{e}$ propicia uma distorção da linguagem, fazendo-a instrumento da elaboração do

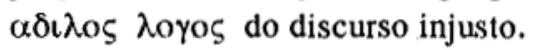

Pouco sabemos, através da narrativa de Tucídides, a respeito das manobras bélicas realizadas em Melos. Sabemos que, após o malogro das conversações, os atenienses construíram uma circunvalação em torno da cidade e os mélios, sitiados, decidiram-se a resistir ao assédio. Por duas vezes conseguiram romper o cerco e obter alguns víveres, mas a capacidade de resistência se esgotou no início do inverno. É no diálogo que acompanhamos realmente a luta, lance a lance, assistindo à construção do muro de assédio, que foi progressivamente isolando os mélios e, de outro lado, as tentativas que estes fizeram para usar das poucas armas, que tinham e para abrir brechas no cerco, que os inimigos lhes impunham.

Já o primeiro momento do debate/combate mostra que os mélios estão acuados. Os atenienses são mais fortes e essa superioridade de forças, manifesta pela própria presença ateniense na ilha, impossibilita e invalida um debate verdadeiro como impossibilitaria e invalidaria um combate. Os mélios mostram a inutilidade das conversações, uma vez que os atenienses não participarão delas

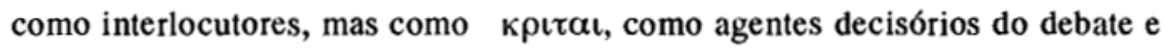

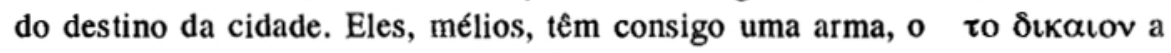
justiça, que lhes poderia garantir a vitória num debate. Reconhecem, porém, que essa arma de nada lhes vale no momento, porque perde a efićácia num confronto com a força bruta. Se, de acordo com a justiça, se recusarem a submeter-se, terão que enfrentar os atenienses numa guerra e, sendo mais fracos, serão escravizados. Os atenienses se recusam a levar em conta qualquer coisa, que não seja o momento presente. Não está em jogo liberdade ou escravidăo, justiça ou injustiça, mas vida ou morte. Numa hora como essa, longos discursos, feitos de palavras bonitas, são descabidos tanto para uns como para outros e é preciso, sem disfarces, falar o que se pensa. Nesse momento os atenienses fazem uma declaração em que definem nitidamente o campo de validade da justiça. Dizem 
PRADO, Amna Lia Amaral de Almeida. O diślogo de Melos: o discurso do poder.

que eles sabem e os mélios também que "de um lado, no cálculo dos homens, os atos justos se decidem quando a pressão é igual e, de outro lado, o que podem os mais fortes fazem e os mais fracos a eles cedem". $(\mathrm{V}, 89)$

Depois dessa declaração, para os mélios a única possibilidade de continuar o debate/combate consiste em por em dúvida a vantagem que os atenienses teriam impedido que os mais fracos tenham seus direitos assegurados ( $\tau \alpha \varepsilon \varepsilon$ เко $\alpha$ $\delta \iota \kappa \alpha \iota \alpha$ ) ou negando-lhes auxílio. A preservação do direito do mais fraco, a solicitude da prestação da ajuda são um koเvov $\alpha \gamma \alpha \vartheta$ ov, um bem comum de que, um dia, talvez os atenienses venham a precisar, quando não estiverem na posição privilegiada do mais forte. Com essa nova arma, o argumento do to

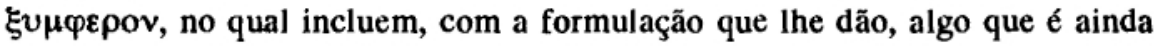

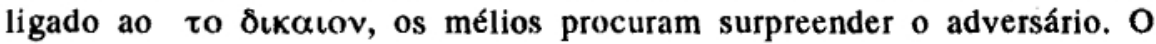
interlocutor todo poderoso, porém, lembra-os que as regras não admitem especulações sobre o futuro, nem previsões sobre riscos eventuais. $O$ que os interessa é apenas a situação presente e isso dizem com palavras ásperas: "A vantagem para o nosso império é a razão de nossa presença aqui e a salvação de vossa cidade a razão das palavras que diremos. Isso vamos demonstrar porque queremos, sem labor, exercer o império sobre vós e, com proveito para ambos, salvar-nos". (V,81)

Respondendo, os mélios tentam mostrar ainda a impossibilidade de enunciar-se como equivalentes o proveito de uns e de outros. Para os atenienses será a $\alpha \rho \chi \eta$, o império, e para eles, a $\delta o v \lambda \varepsilon\llcorner\alpha$, a escravidão. Os mélios não quiseram perceber que não estavam em discussão seu estatuto de homens livres, mas a mera sobrevivência. A vantagem que os atenienses lhes oferecem é apenas continuar vivendo. A sujeição será vantajosa porque, se a aceitarem, evitarão

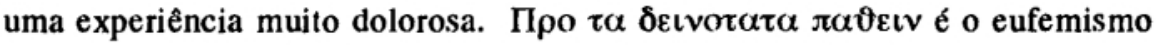
que usam para fugir da palavra morte. $O$ interesse dos atenienses está no crescimento do império e a salvação de Melos é útil para Atenas, na medida em que mais lhe vale anexar uma cidade intacta que arrazada.

Desde que os atenienses não aceitam a neutralidade que os mélios thes oferecem, nem se sensibilizam diante da apreciação desfavorável que seu ato de força poderia ter entre as outras cidades gregas, está caracterizada a impossibilidade de discussão entre eles. A comprovação da desigualdade de força impede o prosseguimento do debate como impedirá também um confronto, que não seja apenas um cerco e os mélios estão na situação de quem recebeu um ultimatum. Estão imobilizados, porque estão cercados, como estarão quando os

$$
-116-
$$


atenienses tiverem construído o muro de assédio. Como mais tarde, em açōes temerárias, sem a menor possibilidade de êxito, tentarão abrir brechas no muro, também agora desafiam aqueles que os assediam. Declaram que, apesar de tudo, sabem de onde tirar forças para resistir.

Estamos agora um segundo momento do diálogo, em que, como diz bem H.-P.Stahl ${ }^{3}$, o debate se volta para o irreal, porque os mélios se recusam a admitir o ultimatum como realidade e, a partir daí, os interlocutores fazem afirmações opostas, sem que possam ter a mínima pretensão a chegar a um acordo.

Os mélios confiam no sentimento de honra de seus concidadãos, que os fará lutar para fugir da escravidão e dizem aos atenienses: "Se tão grandes riscos enfrentais, vós para que vosso império não chegue ao fim e os povos que já são escravos, para dele livrar-se para nós, que somos livres ainda, grande fraqueza e cevardia será não enfrentarmos tudo ao invés de sofrer escravidão". (V,100). A

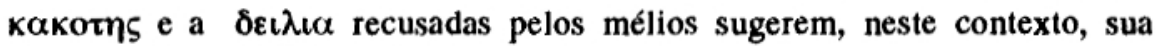
contrapartida, a $\alpha \iota \delta \omega \varsigma / \alpha \iota \sigma \chi v v \eta$, o sentimento de honra. A resposta dos atenienses torna evidente que a $\alpha \iota \delta \omega \varsigma$ é algo válido em espaços em que também a justiça vale e está excluida de um mundo em que impera a força. A $\alpha \iota \delta \varsigma / \alpha \iota \sigma \chi v v \eta$, como a justiça, só tem seu lugar, quando a capacidade de pressāo é igual ( $\varepsilon \xi$ เợ $\varsigma$ $\alpha \alpha \gamma \kappa \eta \zeta)$ porque, como disseram também os delegados atenienses em uma assembléia em Esparta: "Aqueles que têm acesso à força para nada mais precisam do exercício da justiça" (I, 77,2).

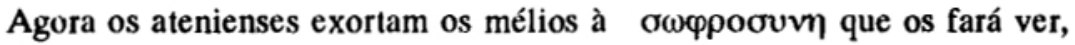
que a luta em que estão empenhados "não é uma disputa de força viril onde se porfia em condições de igualdade para não sofrer desonra. É antes uma deliberação acerca da salvação, onde não cabe resistir aos que são mais fortes".

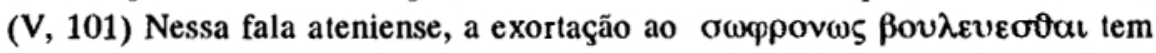
também a função de fazer que os mélios voltem para a realidade de assédio: 0

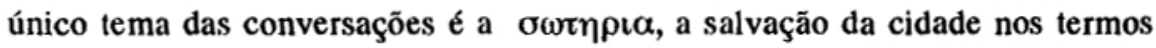
propostos por Atenas.

Nesse momento do diálogo completa-se no discurso dos mélios o que H.P. Stahl chama de salto mortal da inteligência: $\tau v \chi \eta$, aquilo que, por definição, é o incalculável, é algo $\pi \alpha \rho \alpha \lambda o \gamma o v$, é invocada como garantia da realizaçảo de 
PRADO, Anna Lia Amaral de Almeida. O diálogo de Melos: o discurso do poder.

um desejo, como elemento de um plano, como trunfo de uma disputa. Dizem os mélios: "Sabemos que nas guerras, às vezes, as sortes se repartem com mais equidade do que se poderia supor pelo número de combatentes de cada lado. E para nós, o ceder já é algo desesperado, mas com uma ação haverá ainda esperança de permanecer de pé". (V,102)

Na ânsia de buscar forças para a luta de resistência, os mélios pensam então em encontrá-las na esperança de um jogo favorável da sorte. Não percebem isso, dizem nitidamente os atenienses, que combinar a $\tau \hat{\chi} \chi \eta$, a sorte, com a esperança

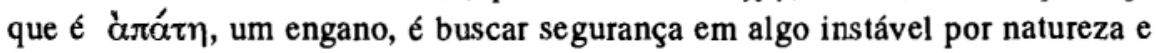
confiar em algo que, por natureza, é enganador.

Os atenienses falam agora num tom solene de advertência e, em suas palavras, onde os comentadores veem um colorido poético, o que vemos concretamente é uma ameaça: "A esperança que é estímulo para o risco, embora traga prejuízo aos que, tendo recursos, convivem com ela, a esses não faz cair, mas aos que põem em jogo tudo o que têm (é pródiga por natureza), ela se dá conhecer no momento em que eles caem e, quando alguém, por tê-la reconhecido, quer dela defender-se, não o abandona. A essa experiência vós, que sois fracos e dependeis de um único impulso da balança, não deveis expor-vos. Não vos igualeis aos que, tendo ainda acesso à salvação por meios humanos, quando estão sendo pressionados e os abandonam as esperanças visíveis, para as incertas se voltam, mântica, oráculos e coisas assim que, juntamente com as esperanças, são nocivas". $(\mathrm{V}, 103)$

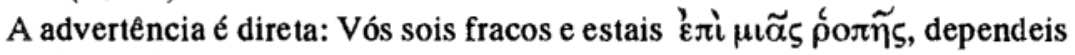
de um único impulso da balança. Isso quer dizer que os mélios estão absolutamente sitiados e a única possibilidade de relaxamento do cerco é admitir a sujeição aos mais fortes, o que os atenienses chamam de avv

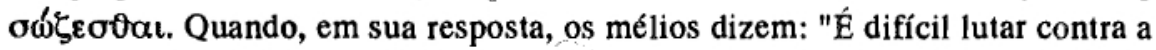
força que tendes e contra a sorte, se não for em pé de igualdade" parece que aprenderam alguma coisa no decorrer das conversações. Sabem que a ' $\alpha v \alpha ́ \gamma \kappa \eta$, que age do lado dos atenienses é maior, sabem que a luta que travam é desigual, que Atenas e Melos não lutarão đarớoov, em pé de igualdade. Entretanto, até no vocabulário que usam mostra que permaneceram surdos às advertências. Eles não dizem: É impossível lutar, mas é difícil, $\chi \alpha \lambda \varepsilon \pi$ róv. Essa palavra nos lembra

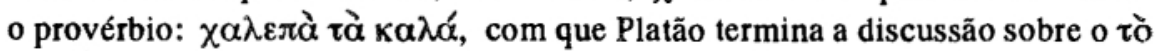

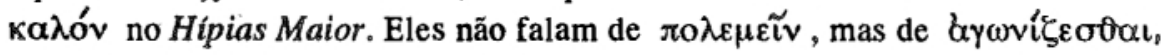
que fala mais de disputa, competição ou que deve vencer o mais viril. Os mélios 


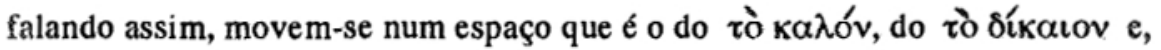
ao referirem-se à ajuda que esperam encontrar nos lacedemônios, no espaço da

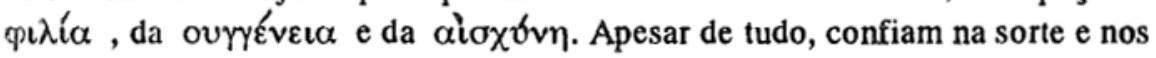
deuses porque são justos e, nos aliados, porque estes, ligados pelo parentesco e pelo sentimento de honra, não lhes faltarão. "Absolutamente não é tão irracional a nossa resistência", terminam eles.

$\mathrm{Na}$ intervenção seguinte, os atenienses procuram abalar a confiança que os mélios tếm nos deuses, fazendo então a declaração formal do direito de dominação do mais forte: "Nada aprovamos ou fizemos que esteja fora do que os homens pensam sobre o divino ou do que querem para si mesmos. Julgamos, de fato, que a divindade (isso é uma opinião), tanto quanto o homem (isso é evidente), por coerção da natureza, onde é mais forte, sempre exerce o império. E essa lei nós não a estabelecemos nem, já estabelecida, fomos os primeiros a usá-la; quando a adotamos, já existia, dela usamos e a deixaremos vigente para sempre, sabendo que também vós e outros, vindo a ter a mesma força que nós, faríeis o mesmo". $(\mathrm{V}, 105)$ Quanto à confiança em Esparta dizem: "Se confiais em que, por sentimento de honra, vos auxiliarão, gabamos a vossa candura, mas não invejamos vossa insensatez". $(\mathrm{V}, 105,3)$ Os lacedemônios prezam a $\alpha \rho \varepsilon \tau \eta$ quando estão no mundo deles. Com os outros, porém, agem de maneira muito diferente. Os atenienses omitem menção a casos concretos que são do conhecimento de todos: a traição de Álcidas aos mitilénios, a farsa do julgamento dos plateenses ou o preço que os aliados de Esparta pagaram pela volta dos prisioneiros de Esfactéria. Mantendo-se longe do caso particular, advertem que nada os mélios devem esperar dos lacedemônios, porque para estes "é belo o que é agradável e justo e vantajoso. Ora, não é a favor de vossa salvação, agora

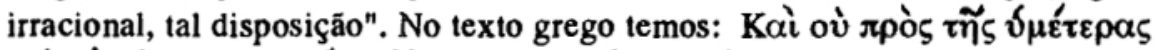

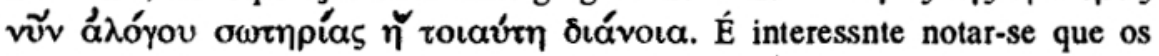

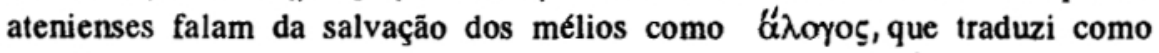

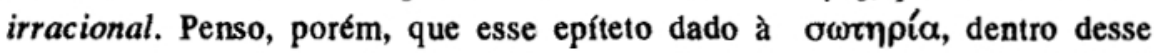
contex to é muito mais significante. Há nessa frase um responso com a afirmação

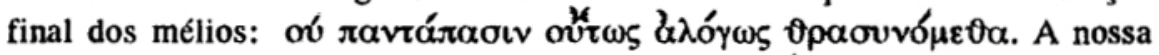

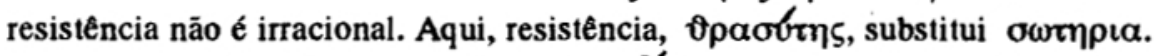
A nossa salvação, dizem os mélios, não é 'á $\lambda$ oyos, sobre ela pode haver um $\lambda$ óyos sobre ela podemos falar, sobre ela podemos calcular, ponderar. Os atenienses refutam essa afirmação dizendo que a salvação dos mélios é 'á $\lambda$ oyos, sobre ela não há $\lambda o ́$ ó possível, nem conversações, nem cálculos. Parece claro 
PRADO, Anna Lia Amaral de Almeich. O diślogo de Melos: o discurso do poder.

que o diálogo propriamente dito termina aqui. O cerco está completo no ' $\alpha \gamma \omega \grave{v} v$

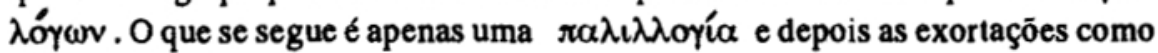
é comum em final de discursos.

Os mélios, depois de uma reunião a sós com os seus, respondem ao ultimatum dizendo que não abrem mão da liberdade de que sua cidade goza há mais de 700 anos.

Os atenienses constroem a circunvalação e os mélios resistem por algum tempo. No início do inverno, os atenienses recebem reforços, os mélios sofrem uma traição e são forçados a entregar seu destino aos atenienses, os mais fortes. E então, termina Tucídides seu relato: "Eles mataram todos os mélios adultos que capturaram, as crianças e mulheres fizeram de escravos. A regiảo eles próprios a ocuparam e para lá mandaram mais tarde quinhentos colonos". (V,116,2)

\section{DIÁLOGO DE MELOS (Tuc. V, 84-116)}

84. No verăo seguinte Alcebíades, tendo navegado até Argos com seus vinte navios, aprisionou os argivos que pareciam suspeitos ainda e estavam de acordo com os lacedemônios, trezentos homens ao todo, e os atenienses os colocaram nas ilhas vizinhas que tinham sob seu império. E também contra a ilha de Melos os atenienses fizeram uma expediçăo com trinta navios seus, seis de Quios, dois de Lesbos; de seus homens levavam mil e duzentos hoplitas, trezentos arqueiros e vinte arqueiros montados e, dos aliados das ilhas, aproximadamente mil e quinhentos hoplitas. 2. Os mélios são colonos dos lacedemonios e não queriam submeter-se aos atenienses como os outros ilhéus; ao contrário, a princípio, sendo neutros, mantinham-se quietos, depois, porque os atenienses os pressionavam, devastando-lhes a terra, puseram-se em guerra aberta. 3. Então, acampados, no território deles com esse aparato, antes de causar qualquer dano à terra, os estrategos Cleomedes, filho de Licomedes, e Tísias, filho de Tisímaco, enviaram delegados para travar negociações. A esses os mélios nảo conduziram diante do povo todo, mas mandaram que, diante das autoridades e dos oligarcas, falassem sobre o objetivo de sua vida. Os atenienese falaram palavras como estas: 
85. "Já que os discursos não se farão diante do povo todo para que a multidão, ouvindo de uma só vez, numa fala ininterrupta, os nossos argumentos persuasivos e irrefutáveis, não seja enganado (sabemos que esse é o sentido de sermos trazidos ao Conselho), membros desta sessão, fazei algo ainda mais seguro. Tomai ponto por ponto e também vós não com um único discurso, mas, ao que não parecer convenientemente dito respondendo imediatamente, decidi. E primeiro dizei se está bem como falamos".

86. Os conselheiros mélios responderam: "Se a generosidade que há no trocarmos informações com tranquilidade não merece censura, os atos de guerra, já presentes e não por vir, parecem nada ter a ver com isso. A vós nós vemos chegar como juízes do que vai ser dito e, de outro lado, o término do debate, como é de esperar, se vencermos com o direito e por isso não nos entregarmos, nós o vemos trazendo-nos guerra e, se submetermos, servidão".

87. Atenienses: "Bem! Se é para raciocinar com suposições sobre o futuro que estais aqui ou para algo que não seja deliberar sobre a salvação da cidade a partir do presente e do que estais vendo, desistiremos; se para isso, falaremos".

88. Mélios: "natural e desculpável é quem está numa situação como esta voltar-se para muitas direções falando e também ponderando. Esta reunião, todavia, é também sobre a nossa salvação e a discussão se faça do modo que sugeris, se assim vos parece".

89. Atenienses: "Bem! Nós, de nosso lado, não usaremos palavras bonitas dizendo que por direito, tendo vencido os medos, exercemos o império ou que, feridos em nosso direito, vos atacamos. Não faremos um discurso longo, não digno de fé e esperamos que vós não pretendais persuadir-nos dizendo ou que, sendo colonos dos lacedemônios não vos aliastes a eles, ou que em nada fostes contra nossos direitos. Realizai, ao contrário, o possível a partir do que pensamos realmente uns e outros, já que nós e vós sabemos que, se o direito, no cálculo humano, é decidido quando a coerção é equivalente, o que podem os mais fortes fazem e os mais fracos a eles cedem".

90. Mélios: "Por isso é que consideramos útil (não temos outra saída, já que a vossa proposta é esta, enunciar o vantajoso, excluindo o direito) que não anuleis o bem comum, mas, se alguém está em risco, que tenha em cada vez os direitos habituais e também, se a alguém conseguir persuadir mesmo aquém do limite exato, que obtenha uma ajuda. E para vós isso não é de menor valor tanto mais que, no caso de uma derrota, sofrendo uma punição muito pesada, viríeis a ser exemplos para os outros". 
PRADO, Anna Lia Amaral de Almeida. O diálogo de Melos: o discurso do poder.

91. Atenienses: "Mas nós, do fim de nosso império, se é que ele acabará não temos medo. Não, não são os detentores de império sobre outros, como os lacedemônios, os mais temíveis para os vencimentos (e nossa disputa não é contra os lacedemónios), mas os súditos, se, um dia, eles próprios atacando, dominarem os que detêm o império. 2. Também a esse respeito deixai-nos correr o riscol $\mathrm{A}$ vantagem para o nosso império é a razão de nossa presença e a salvação de vossa cidade e das palavras que vamos dizer. Eis o que vamos demonstrar, querendo sem labor ter o império sobre vós e com vantagem para ambos os lados salvar-nos".

92. Mélios: "E como? Para nós sofrer escravidão seria tão útil quanto para vós exercer o império?

93. Atenienses: "Para vós a submissão ocorreria antes de sofrer mais terríveis provações e, quanto a nós, sem destruir-vos, lucraríamos".

94. Mélios: "Assim, que nós, mantendo-nos em paz, fôssemos amigos ao invés de inimigos e aliados nem de uns nem de outros não aceitaríeis?"

95. Atenienses: "Não! Não nos prejudica tanto a vossa hostilidade quanto a amizade - esta dá aos que estão sob o império uma prova de fraqueza, mas o ódio uma de força".

96. Mélios: "É essa a visão que os vossos súditos têm do que é adequado? Aos que convosco nada têm a ver, aos que sendo colonos (e são a maioria) e aos que, tendo-se rebelado (e são alguns), foram submetidos, eles porão no mesmo plano?"

97. "Razão de direito não falta nem a uns nem a outros, julgam eles: na medida da força que têm uns sobrevivem e nós por medo não agredimos. Sendo assim, além do império sobre um maior número, também segurança proporcionaríeis com vossa submissão, principalmente porque sois ilhéus e nós os donos do mar e porque sois mais fracos que os outros".

98. Mélios: "E naquela outra proposta não acreditais que haja segurança? De nosso lado, neste ponto também, do mesmo modo que nos forçais a sair dos argumentos de direito e tentais persuadir-nos a submeter-nos ao vosso interesse, é preciso que, também nós, enunciando o que é útil para nós, se coincide como o que é útil para vós, tentemos persuadir-vos. Os que se mantêm neutros, como deixarieis de tê-los como inimigos quando, olhando para estes acontecimentos, vierem a pensar que um dia vós os atacareis? E, nesse momento, que outra coisa faríeis senão fortalecer os inimigos que já tendes e atrair outros que viriam de mau grado, nunca tendo pensado em opor-se a vós?" 
99. Atenienses: "Não, não consideramos os mais temíveis para nós os continentais que são livres e hesitarão muito em opor-se em guarda contra nós. Não a esses mas aos ilhéus, os que estão fora do império como vós e os que, exaltados, se irritam com a coerção de nosso império. São esses que mais se voltariam para o irracional e colocariam a si próprios e a nós também diante de um risco visível".

100. Mélios: "Ora, se tão grande risco enfrentais, vós para que vosso império não tenha fim, os povos que são escravos para dele livrarem-se, para nós, que somos livres ainda, grande fraqueza e covardia será não preferir tudo enfrentar a ser escravo".

101. Atenienses: "Não será, se deliberardes com sabedoria. Isto não é uma disputa de força viril onde se porfia em condições de igualdade para não sofrer desonra. É antes uma deliberação acerca da salvação onde se trata de não resistir aos que são muito mais fortes".

102. Mélios: "Mas sabemos que nas guerras, às vezes, a sorte cabe a ambos os lados de maneira mais igual do que se poderia esperar em vista da diferença numérica entre eles. E para nós o ceder é já algo desesperado, mas como um ato haverá ainda esperança de permanecermos de pén.

103. Atenienses: "A esperança que é estímulo para o risco, embora traga prejuízo aos que, tendo recursos, convivem com ela, a esses não faz cair, mas aos que põe em jogo tudo o que têm (é pródigo por natureza) ela se dá a conhecer no momento em que eles caem e, quando alguém, por tê-la reconhecido, quer dela defender-se, não o abandona. A essa experiência, vós, que sois fracos e dependeis de um único impulso de balança, não deveis expor-vos. Não vos igualeis aos que, tendo ainda acesso à salvação por meios humanos, quando estão sendo pressionados e os abandonam as esperanças visíveis, para as incertas se voltam, mântica, oráculos e coisas assim que, juntamente com as esperanças, são nocivas".

104. Mélios: "Difícil também, nós julgamos, sabeis bem, lutar contra a força que tendes e contra a sorte, se não for em pé de igualdade. Apesar disso temos confiança! Em sorte a divindade não nos fará menores porque, piedosos, estamos diante de não justos e, de outro lado, para o que nos falta de força contaremos com a liga lacedemônica que, se nâo por outro motivo, por causa de nosso parentesco e em nome da honra, será forçada a ajudar-nos. E absolutamente não é tão irracional a nossa segurança!" 
PRADO, Anna Lia Amaral de Almeich. O diálogo de Melos: o discurso do poder.

105. Atenienses: "Ora, quanto à boa disposição por parte da divindade também nós julgamos não ficar atrás. Nada aprovamos ou fizemos que esteja fora do que os homens pensam sobre o divino ou do que querem para si mesmos. 2. Julgamos, de fato, que a divindade (isso é uma opinião) tanto quanto o homem (isso é evidente), por coerçāo da natureza, onde é mais forte sempre exerce o império. E essa lei nós não a estabelecemos nem, já estabelecida, fomos os primeiros a usá-la. Quando a adotamos, já existia, dela usamos e a deixaremos vigente para sempre, sabendo que também vós e outros, vindo a ter a mesma força que nós, faríeis o mesmo. 3. E assim quanto à divindade é natural que não temamos que nos faça menores. Quanto à vossa opinião sobre os lacedemônios, se confiais em que por sentimento de honra vos auxiliarăo, gabamos a vossa candura, mas não invejamos vossa insensatez. 4. Os lacedemônios entre si e nas instituições de sua terra mostram muita virtude, mas, sobre como se comportam com os outros, embora muita coisa se pudesse dizer, numa palavra, o mais importante a demonstrar é que, dentre os povos que conhecemos, são eles quem, de maneira mais evidente, julga belo o que é agradável e justo o que é vantajoso. Ora, não é a favor de vossa salvação, agora irracional, tal disposição".

106. Mélios: "Ao contrário, nós temos confiança por isso mesmo. Por interesse deles próprios, não quererão trair os mélios, seus colonos, tornando-se suspeitos para os que, na Hélade, são seus amigos, e úteis para os que são inimigos".

107. Atenienses: "Não julgais que o interesse vem junto com a segurança e que o justo e o belo se realizam junto com o risco? Esse risco em geral os lacedemônios muitíssimo pouco ousam correr".

108. Mélios: "Mas os riscos por nossa causa julgamos que eles assumirão e também que conosco se sentirão mais seguros que com outros, porque, sob o ponto de vista prático (estamos situados perto do Peloponeso) e sob o ponto de vista moral (pelo parentesco) somos mais dignos de fé que os outros".

109. Atenienses: "A segurança para os que vão participar de uma luta não é a boa disposição dos que os chamam em auxílio, mas a capacidade superior de ação. Isso é o que os lacedemônios, mais que os outros, tem em vista (é, por exemplo, por falta de confiança nos recursos próprios que, até quando atacam seus vizinhos, vão com muitos aliados), de forma que não é de esperar que, sendo vós os senhores do mar, façam eles a travessia até uma ilha".

110. Mélios: "Mas eles também poderiam mandar outros. É vasto o mar de Creta e nesse mar é mais inviável a captura para os que aí exercem o domínio que a salvação para quem quer passar despercebido. E se nisso falhassem, 
voltar-se-iam contra a vossa terra e contra o resto dos aliados aos quais Brásidas não teve acesso e a vossa luta não será tanto por uma terra com que nada tendes quanto por uma aliança e terra que vos toca mais de perto".

111. Atenienses: "Algo disso poderia ocorrer quando já tivésseis experiências e não deixásseis de saber que jamais um assédio, um que fosse, os atenienses abandonaram por medo de outros. 2. Mas estávamos pensando que, tendo concordado em falar a respeito de vossa salvação, em tão longo debate, nada falastes que a homens desse razões para confiar em que seriam salvos. Ao contrário, os mais fortes apoios com que contais, esperanças apenas, tardam e os recursos que já tendes são curtos para resistir a forças que estão postas contra vós. Muita irracionalidade de pensamento mostrais se, depois de deixar-nos, não tomardes ainda outra decisão mais sensata do que estas. 3. Ao sentimento de honra que, na maioria das vezes, a homens que estão em situaçōes humilhantes e riscos iminentes, destróis, não vos entregueis! A muitos que ainda podiam ver para onde estavam sendo levados, a chamada honra arrastou com a força de um termo sedutor e, vencidos por uma palavra, de bom grado cairam de fato em sofrimentos sem remédio e, além disso, sofreram vergonha que, vinda da ignorância, é mais vergonhosa que a trazida pela sorte. 4. É disso que vós, se deliberardes bem, vos guardareis. Não julgareis infamante ceder a uma cidade muito poderosa que vos faz propostas moderadas - sereis aliados, conservarieis vosso território, mas pagareis tributo - nem tão pouco, sendo-vos dada entre guerra e segurança, desistir de lutar pelo pior. Os que não cedem aos iguais, os que tratam bem os mais fortes e são moderados com os mais fracos são os que têm mais éxito. 5. Atentai, portanto, e depois de sairmos, refleti por muitas vezes que estais deliberando a respeito da pátria que é uma só e que, com uma só decisão, conforme seja feliz ou não, poderá manter-se de pé".

112. Os atenienses se retiraram e os mélios, depois que ficaram a sós, já que o decidido não divergia de sua argumentação no debate, responderam o seguinte: 2. "Nem nossas decisões são outras que as iniciais, atenienses, nem iremos num instante privar de sua liberdade uma cidade de setecentos anos de existência, mas, confiantes na sorte que, vinda da divindade, a preserva até hoje e no socorro que virá dos homens - dos lacedemônios -, tentaremos salvá-la. 3. Propomo-vos que sejamos vossos amigos, que nos mantenhamos neutros e que vos retireis de nosso território, depois de fazer um tratado que pareça adequado a ambos os lados".

113. Os mélios só isso responderam e os atenienses, interrompendo as conversações, declararam: "Ora, de fato, por essas decisões, vós sois os únicos que, segundo parece, discernis as coisas futuras mais nitidamente do que as que estais vendo e as incertas, por desejá-las, já estais vendo como existentes. 
PRADO, Anna Lia Amaral de Almeida. O diálogo de Melos: o discurso do poder.

Entregues aos lacedemônios, à sorte e à esperança e neles confiando de maneira total, total será também vossa queda".

114. Os delegados atenienses regressaram para junto de suas tropas e os estrategos, já que os mélios em nada os atenderam, imediatamente puseram-se em guerra e, tendo dividido a tarefa entre as cidades construiram um muro de assédio em redor da cidade dos mélios. 2. Mais tarde os atenienses deixaram soldados seus e dos aliados para montar guarda por terra e por mar e retiraram-se com a maioria da tropa. Os que ficaram continuaram sitiando o local.

115. E os argivos, durante esse tempo, depois de invadir o território de Flionte, emboscados por fliásios e por exilados de sua cidade, foram mortos num total de oitenta homens. 2. Os atenienses que agiam a partir de Pilos tomaram dos lacedemónios uma grande presa. $\mathrm{E}$ os lacedemónios em vista disso não romperam a trégua, nem entraram em guerra contra eles, mas proclamaram, através de arauto, que dos seus quem quisesse pilhasse os atenienses. 3. Os coríntios, por certas divergências privadas, entraram em guerra com os atenienses, mas os outros peloponésios mantinham-se quietos.

4. Os mélios tomaram dos atenienses a parte de circunvalação correspondente à ágora, atacando-a durante a noite; mataram homens e, fazendo entrar alimentos e o máximo que puderam do que lhes era útil, retiraram-se mantendo-se quietos. E os atenienses, a partir de então, procuravam aprestar melhor a guarda. $O$ verảo chegava ao fim.

116. No verâo seguinte os lacedemônios que estavam para fazer campanha contra Argos, como na fronteira os sacrifícios pela travessia nāo chegaram a seu termo, retiraram-se. Os argivos por causa dessa tentativa dos lacedemónios suspeitaram de algumas pessoas da cidade. A algumas eles aprisionaram, mas outras conseguiram escapar.

2. Os mélios, mais ou menos nessa ocasião, outra vez tomaram uma parte da circunvalação dos atenienses, por não serem muitos os guardas presentes. 3 . E mais tarde, por causa do ocorrido, chegou de Atenas uma outra tropa, comandada por Filócrates, filho de Dêmeas. Quando já estavam sob rigoroso assédio e também houve traiçāo de um dos seus, os mélios entraram em acordo com os atenienses aceitando que decidissem sobre seu destino. 4. Eles mataram todos os mélios adultos que capturaram, as crianças e mulheres fizeram escravos. A regiāo eles próprios a ocuparam e para lá mandaram mais tarde quinhentos colonos. 